\title{
Novel Bile Acid-based Cyclic Bis- imidazolium Receptors for Anion Recognition
}

\author{
Vijay K. Khatri, Shailesh Upreti ${ }^{+}$and Pramod S. Pandey* \\ Department of Chemistry, Indian Institute of Technology, Hauz Khas, New Delhi, \\ 110016, India.Fax: (+91)11-26582037. \\ pramod@chemistry.iitd.ac.in
}

\section{Experimental}

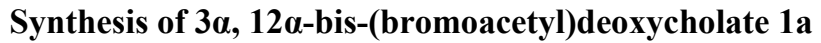

Methyl deoxycholate $(3.0 \mathrm{~g}, 7.36 \mathrm{mmol})$ was dissolved in dry chloroform $(20 \mathrm{~mL})$. Anhydrous $\mathrm{K}_{2} \mathrm{CO}_{3}(2.04 \mathrm{~g}, 14.7 \mathrm{mmol})$ and bromoacetyl bromide were added to it and the reaction mixture was stirred for $12 \mathrm{~h}$ at room temperature. After the completion of reaction, $5 \mathrm{~mL}$ of water was added. The chloroform layer was separated and washed with $5 \mathrm{~mL}$ of saturated sodium bicarbonate solution and then with water $(10 \mathrm{~mL})$. The chloroform layer was dried over anhydrous sodium sulfate. The chloroform layer was filtered and evaporated completely. The residue was purified by column chromatography on silica gel $(20 \%(\mathrm{v} / \mathrm{v})$ ethyl acetate in hexane and product obtained as sticky solid. Yield: $(88 \%)$.

${ }^{1} \mathrm{H}$ NMR $\left(300 \mathrm{MH}_{\mathrm{Z}}, \mathrm{CDCl}_{3}, \mathrm{TMS}\right) \delta 0.74$ (s, 3H, 18-Me), 0.83 (bs, 3H, 21-Me), 0.92 (s, 3H, 19-Me), 1.01-2.31 (26H, steroidal H), $3.66\left(\mathrm{~s}, 3 \mathrm{H}, \mathrm{OCH}_{3}\right), 3.79\left(\mathrm{~s}, 2 \mathrm{H}, \mathrm{CH}_{2} \mathrm{Br}\right), 3.89\left(\mathrm{~s}, 2 \mathrm{H}, \mathrm{CH}_{2} \mathrm{Br}\right), 4.76(\mathrm{~s}, 1 \mathrm{H}, 3 \beta-\mathrm{H}), 5.16(\mathrm{brs}, 1 \mathrm{H}, 12 \beta-\mathrm{H})$.

\section{Synthesis of $3 \alpha, 12 \alpha$-bis- $\left\{\mathrm{O}-\left(\mathrm{N}_{1}\right.\right.$-imidazole $)$ acetyl $\}$ deoxycholate 2}

$3 \alpha, 12 \alpha$-bis-(bromoacetyl)deoxycholate $1 \mathrm{a}(2.0 \mathrm{~g}, 3.08 \mathrm{mmol})$ was dissolved in dry DMF $(7 \mathrm{~mL})$ and imidazole $(0.83 \mathrm{~g}$, $12.3 \mathrm{mmol}$ ) was added to it and reaction mixture was stirred at room temperature for $24 \mathrm{~h}$. After the completion of reaction, the reaction mixture was poured into ice cold water. The white solid obtained was filtered and dry under vacuum. The product was purified by column chromatography $\left(5 \%(\mathrm{v} / \mathrm{v})\right.$ methanol in chloroform). Yield: $65 \% ; \mathrm{mp}: 120^{\circ} \mathrm{C}$

${ }^{1} \mathrm{H}$ NMR (300 $\mathrm{MH}_{\mathrm{Z}}, \mathrm{CDCl}_{3}$, TMS) $\delta 0.70$ (s, 3H, 18-Me), 0.80 (bs, 3H, 21-Me), 0.92 (s, 3H, 19-Me), 1.01-2.39 (26H,

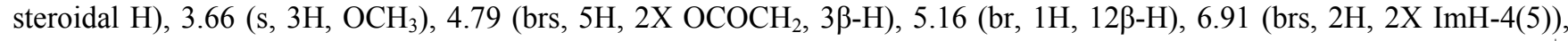
7.07 (s, 1H, ImH-5(4)), 7.12 (s, 1H, ImH-5(4)), 7.52 (s, 1H, ImH-2), 7.57 (s, 1H, ImH-2). MS (FAB) m/z 624 [M+H] ; Anal.calcd for $\mathrm{C}_{35} \mathrm{H}_{50} \mathrm{~N}_{4} \mathrm{O}_{6} . \mathrm{H}_{2} \mathrm{O}: \mathrm{C}, 65.60 ; \mathrm{H}, 8.18 ; \mathrm{N}, 8.74$; found: C, 65.46; H, 8.14; N, 8.96.

\section{Synthesis of 3-(Br)}

$3 \alpha, 12 \alpha$-bis- $\left\{\mathrm{O}\right.$-( $\mathrm{N}_{1}$-imidazole)acetyl $\}$ deoxycholate $2(100 \mathrm{mg}, 0.16 \mathrm{mmol})$ and $\mathrm{m}$-xylylene bromide $(42 \mathrm{mg}, 0.16 \mathrm{mmol})$ was dissolved in $70 \mathrm{~mL}$ of dry acetonitrile and solution was reflux for $4 \mathrm{~h}$. After the completion of reaction, reaction mixture was allowed to cool at room temperature. Acetonitirle was evaporated completely and residue was recrystallized using chloroform and hexane to obtain pure product as white crystalline solid. Yield: $85 \%$; mp: decomposed at $189^{\circ} \mathrm{C}$

Analytical data for 3-(Br) 2 : ${ }^{1} \mathrm{H}$ NMR $\left(300 \mathrm{MHz}, \mathrm{CDCl}_{3}, \mathrm{TMS}\right) \delta 0.73(\mathrm{~s}, 3 \mathrm{H}, 18-\mathrm{Me}), 0.82(\mathrm{~d}, 3 \mathrm{H}, 21-\mathrm{Me}), 0.88(\mathrm{~s}, 3 \mathrm{H}$, 19-Me), 0.97-2.34 (26H, steroidal H), $3.66\left(\mathrm{~s}, 3 \mathrm{H}, \mathrm{OCH}_{3}\right), 4.55(3 \beta-\mathrm{H}), 4.72\left(\mathrm{~d}, 1 \mathrm{H}, \mathrm{J}=16.5, \mathrm{OCOCH}_{2}\right), 4.98(\mathrm{~d}, \mathrm{~J}=18.3$, $\left.\mathrm{OCOCH}_{2}\right), 5.17(\mathrm{bs}, 1 \mathrm{H}, 12 \beta-\mathrm{H}), 5.54\left(\mathrm{~m}, 2 \mathrm{H}\right.$, benzylic $\left.\mathrm{CH}_{2}\right), 5.80\left(\mathrm{~m}, 2 \mathrm{H}\right.$, benzylic $\left.\mathrm{CH}_{2}\right), 5.92(\mathrm{~d}, 1 \mathrm{H}, \mathrm{J}=16.5, \mathrm{OCOCH})$, $6.12\left(\mathrm{~d}, \mathrm{~J}=18.3, \mathrm{OCOCH}_{2}\right), 7.36-7.44(\mathrm{~m}, 3 \mathrm{H}, \mathrm{ArH}), 7.55(\mathrm{~s}, 1 \mathrm{H}, \mathrm{ArH}), 7.58(\mathrm{~s}, 1 \mathrm{H}, \mathrm{ImH}-4(5)), 7.76(\mathrm{~s}, 1 \mathrm{H}, \mathrm{ImH}-4(5)), 8.24$ $(\mathrm{s}, 1 \mathrm{H}, \mathrm{ImH}-5(4)), 8.36(\mathrm{~s}, 1 \mathrm{H}, \mathrm{ImH}-5(4)), 10.07$ (s, 1H, ImH-2), $10.14(\mathrm{~s}, 1 \mathrm{H}, \mathrm{ImH}-2) .{ }^{13} \mathrm{C} \mathrm{NMR}\left(75 \mathrm{MHz}, \mathrm{CDCl}{ }_{3}, \mathrm{TMS}\right) \delta$ $12.42,17.85,22.81,23.47,25.68,25.79,25.95,26.78,27.52,30.95,31.17,31.52,34.03,34.23,34.52,34.95,35.49,41.66$, $45.36,47.18,49.31,50.01,50.48,51.81,53.51,78.26,79.79,123.12,123.25,123.54,123.65,129.97131 .22,131.63,132.17$, 
133.28, 133.62, 137.65, 138.27, 165.82, 174.98; MS (ESI) m/z 806.85 [M-Br] Anal. calcd for $\mathrm{C}_{43} \mathrm{H}_{58} \mathrm{Br}_{2} \mathrm{~N}_{4} \mathrm{O}_{6} .3 \mathrm{H}_{2} \mathrm{O}: \mathrm{C}$, $54.90 ; \mathrm{H}, 6.86 ; \mathrm{N}, 5.96$; found: C, 54.71; H, 6.66; N, 6.20 .

\section{Synthesis of 4-(Br) $)_{2}$}

$3 \alpha, 12 \alpha$-bis- $\left\{\mathrm{O}\right.$ - $\left(\mathrm{N}_{1}\right.$-imidazole $)$ acetyl $\}$ deoxycholate $2(100 \mathrm{mg}, 0.16 \mathrm{mmol})$ and $\mathrm{p}$-xylylene bromide $(42 \mathrm{mg}, 0.16 \mathrm{mmol})$ was dissolved in $70 \mathrm{~mL}$ of dry acetonitrile and solution was reflux for $6 \mathrm{~h}$. After the completion of reaction, reaction mixture was allowed to cool at room temperature. Acetonitirle was evaporated completely and residue was recrystallized using chloroform and methanol to obtain pure product as white crystalline solid. Yield: $80 \%$; mp: decomposed at $218^{\circ} \mathrm{C}$

Analytical data for 4-(Br) $)_{2}:{ }^{1} \mathrm{H}$ NMR $\left(300 \mathrm{MHz}, \mathrm{CDCl}_{3}, \mathrm{TMS}\right) \delta 0.73(\mathrm{~s}, 3 \mathrm{H}, 18-\mathrm{Me}), 0.80(\mathrm{~d}, 3 \mathrm{H}, 21-\mathrm{Me}), 0.88(\mathrm{~s}, 3 \mathrm{H}$, 19-Me), 1.10-2.35 (26H, steroidal H), $3.66\left(\mathrm{~s}, 3 \mathrm{H}, \mathrm{OCH}_{3}\right), 4.51(3 \beta-\mathrm{H}), 4.66\left(\mathrm{~d}, 1 \mathrm{H}, \mathrm{J}=16.8, \mathrm{OCOCH}_{2}\right), 4.80(\mathrm{~d}, \mathrm{~J}=18.3$, $\left.\mathrm{OCOCH}_{2}\right), 5.19(\mathrm{bs}, 1 \mathrm{H}, 12 \beta-\mathrm{H}), 5.56-5.81\left(\mathrm{~m}, 4 \mathrm{H}, 2 \mathrm{X}\right.$ benzylic $\left.\mathrm{CH}_{2}\right), 6.01\left(\mathrm{~d}, 1 \mathrm{H}, \mathrm{J}=16.8, \mathrm{OCOCH}_{2}\right), 6.54(\mathrm{~d}, \mathrm{~J}=18.3$, $\left.\mathrm{OCOCH}_{2}\right), 7.33$ (s, 1H, ImH-4(5)), 7.46 (s, 1H, ImH-4(5), 7.50-7.58 (m,4H, ArH), 8.36 (bs,2H, 2X ImH-5(4)), 9.80 (s, $1 \mathrm{H}$, ImH-2), 9.90 (s, 1H, ImH-2): ${ }^{13} \mathrm{C}$ NMR (75 MHz, $\mathrm{CDCl}_{3}$, TMS) $\delta 11.95,17.23,22.48,23.06,25.37,26.50,27.12,30.44$, $30.79,31.30,33.98,34.54,35.17,41.28,44.95,46.89$, 48.74, 49.44, 50.27, 51.40, 53.36, 77.99, 78.92, 122.50, 123.72, 124.01 131.97, 132.28, 136.88, 137.25, 166.18, 175.10: MS (ESI) m/z $806.80[\mathrm{M}-\mathrm{Br}]^{+}$Anal. calcd for $\mathrm{C}_{43} \mathrm{H}_{58} \mathrm{Br}_{2} \mathrm{~N}_{4} \mathrm{O}_{6} .1 .5 \mathrm{H}_{2} \mathrm{O}: \mathrm{C}, 56.52 ; \mathrm{H}, 6.73 ; \mathrm{N}, 6.13$; found: $\mathrm{C}, 56.16 ; \mathrm{H}, 6.68 ; \mathrm{N}, 6.29$.

\section{General procedure for anion exchange of dibromide salts of receptors with $\mathrm{NH}_{4} \mathrm{PF}_{6}$}

Dibromide salt $(100 \mathrm{mg})$ of receptor was added to saturated methanolic solution of $\mathrm{NH}_{4} \mathrm{PF}_{6}(5 \mathrm{~mL})$ and stirred for $1 \mathrm{~h}$. White precipitate of product obtained was filtered and washed with methanol and then dried under vacuum. Yield: $80-90 \%$

Analytical data for 3-( $\left.\mathrm{PF}_{6}\right)_{2}:{ }^{1} \mathrm{H} \mathrm{NMR}\left(300 \mathrm{MH}_{\mathrm{z}}, \mathrm{CDCl}_{3}, \mathrm{TMS}\right) \delta 0.72(\mathrm{~s}, 3 \mathrm{H}, 18-\mathrm{Me}), 0.80(\mathrm{bs}, 3 \mathrm{H}, 21-\mathrm{Me}), 0.88(\mathrm{~s}, 3 \mathrm{H}$, 19-Me), 1.01-2.31 (26H, steroidal H), $3.64\left(\mathrm{~s}, 3 \mathrm{H}, \mathrm{OCH}_{3}\right), 4.49(3 \beta-\mathrm{H}), 4.78\left(\mathrm{~d}, 1 \mathrm{H}, \mathrm{J}=16.5, \mathrm{OCOCH}_{2}\right), 4.97(\mathrm{~d}, \mathrm{~J}=16.5$, $\left.\mathrm{OCOCH}_{2}\right), 5.04$ (bs, 2H, OCOCH$)_{2}, 5.26\left(\mathrm{~m}, 5 \mathrm{H}, 2 \mathrm{X}\right.$ benzylic $\left.\mathrm{CH}_{2}, 12 \beta-\mathrm{H}\right), 7.30-7.46(\mathrm{~m}, 8 \mathrm{H}, 4 \mathrm{ArH}, 2 \mathrm{X} \operatorname{ImH}-4(5), 2 \mathrm{X}$ ImH-5(4)), 8.18 (bs, 2H, 2X ImH-2); MS (FAB) m/z $872\left[\mathrm{M}-\mathrm{PF}_{6}\right]^{+}$; Anal. calcd for $\mathrm{C}_{43} \mathrm{H}_{58} \mathrm{~F}_{12} \mathrm{~N}_{4} \mathrm{O}_{6} \mathrm{P}_{2} .3 \mathrm{H}_{2} \mathrm{O}: \mathrm{C}, 48.23$; H, $6.02 ; \mathrm{N}, 5.23$; found: $\mathrm{C}, 47.77 ; \mathrm{H}, 5.67 ; \mathrm{N}, 5.33$.

Analytical data for 4-( $\left.\mathrm{PF}_{6}\right)_{2}:{ }^{1} \mathrm{H}$ NMR $\left(300 \mathrm{MHz}, \mathrm{CDCl}_{3}, \mathrm{TMS}\right) \delta 0.72(\mathrm{~s}, 3 \mathrm{H}, 18-\mathrm{Me}), 0.80$ (bs, 3H, 21-Me), 0.87 (s, 3H, 19-Me), 1.09-2.33 (26H, steroidal H), $3.64\left(\mathrm{~s}, 3 \mathrm{H}, \mathrm{OCH}_{3}\right), 4.48(3 \beta-\mathrm{H}), 4.65\left(\mathrm{~d}, 1 \mathrm{H}, \mathrm{J}=16.5, \mathrm{OCOCH}_{2}\right), 4.90(\mathrm{~d}, \mathrm{~J}=16.5$, $\mathrm{OCOCH}_{2}$ ), 5.13-5.31 (m, 7H, 2X benzylic $\left.\mathrm{CH}_{2}, \mathrm{OCOCH}_{2}, 12 \beta-\mathrm{H}\right), 7.45-7.48(\mathrm{~m}, 6 \mathrm{H}, 4 \mathrm{ArH}, 2 \mathrm{X} \mathrm{ImH}-4(5)), 7.60$ (bs, 2H, $2 \mathrm{X} \mathrm{ImH}-5(4)), 8.10(\mathrm{~s}, 1 \mathrm{H}, \mathrm{ImH}-2), 8.21(\mathrm{~s}, 1 \mathrm{H}, \mathrm{ImH}-2)$; $\mathrm{MS}(\mathrm{ESI}) \mathrm{m} / \mathrm{z} 872\left[\mathrm{M}-\mathrm{PF}_{6}\right]^{+}$. Anal. calcd for $\mathrm{C}_{43} \mathrm{H}_{58} \mathrm{~F}_{12} \mathrm{~N}_{4} \mathrm{O}_{6} \mathrm{P}_{2}: \mathrm{C}_{\text {, }}$ $50.79 ; \mathrm{H}, 5.75 ; \mathrm{N}, 5.51$; found: $\mathrm{C}, 50.07 ; \mathrm{H}, 5.56 ; \mathrm{N}, 5.82$.

\section{Crystallographic Analysis}

X-Ray diffraction studies of crystals mounted on a capillary were carried out on a BRUKER AXS SMART-APEX diffractometer with a CCD area detector $\left(\mathrm{K}_{\alpha}=0.71073 \AA\right.$, monochromator: graphite). Frames were collected by $\omega, \phi$, and $2 \theta-$ rotation at $10 \mathrm{~s}$ per frame with SAINT. The measured intensities were reduced to $\mathrm{F}^{2}$ and corrected for absorption with SADABS. Structure solution, refinement, and data output were carried out with the SHELXTL program. Non-hydrogen atoms were refined anisotropically. Hydrogen atoms for water molecules $\mathrm{O} 1 \mathrm{~W}$ and $\mathrm{O} 2 \mathrm{~W}$ in $3-(\mathrm{Br})_{2} \cdot 2 \mathrm{CHCl}_{3} \cdot 2 \mathrm{H}_{2} \mathrm{O}$ and $\mathrm{O} 2 \mathrm{~W}$ in $4-(\mathrm{Br})_{2} \cdot 1.5 \mathrm{H}_{2} \mathrm{O}$ could not be located from the difference map. $\mathrm{C}-\mathrm{H}$ hydrogen atoms were placed in geometrically calculated positions by using a riding model and isotropic temperature factors were fixed. Figures were created with the Diamond program. Hydrogen bonding interactions in the crystal lattice were calculated with SHELXTL and Diamond.

\section{${ }^{1}$ H NMR Titration Method}

All NMR experiments were performed on a Bruker DPX300 (300 MHz) spectrometer at $298 \mathrm{~K}$. A solution $(10 \mathrm{mM})$ of receptors in $\mathrm{CDCl}_{3}$ was titrated with aliquots from stock solution of tetrabutylammonium salts $(40-60 \mathrm{mM})$ in the same solvent. The chemical shift changes of the $\mathrm{C}(2)$ proton of imidazolium units in receptors were monitored. The association constants $\mathrm{K}_{\mathrm{a}}$ were calculated using the WinEQNMR computer program. Every titration was repeated at least once until consistent results were obtained. The association constants $\mathrm{K}_{\mathrm{a}}$ were calculated using the WinEQNMR computer program. Every titration was repeated at least once until consistent results were obtained.

The complex stoichiometry was determined by using Job's method of continuous variations. Solutions of equal concentration $(10 \mathrm{mM})$ of the host (receptor) and guest (tetrabutylammonium salt) were made in $\mathrm{CDCl}_{3}$. In 9 separate $\mathrm{NMR}$ tubes the solutions of the host and guest were mixed in different proportions in such a way that the ratio of each component varied but the total volume of the mixture was kept constant $(0.5 \mathrm{~mL})$. A plot of the product of the host concentration and 
difference in chemical shifts of $\mathrm{C}(2)-\mathrm{H}$ proton of imidazolium ring vs the guest mole fraction was drawn. This peaked at the guest mole fraction of 0.5 , indicating $1: 1$ stichiometry in solution.

\section{Two Dimensional Heteronuclear Single Quantum Coherence (HSQC) Studies}

The expanded HSQC spectrum of $\mathbf{3}-(\mathrm{Br})_{2}$ in $\mathrm{CDCl}_{3}$ is shown in figure $\mathbf{S 1}$. The crosspeaks $1 ; 2$ and 3; 4 at $\delta 50.01 / 6.14$; $50.01 / 6.08$ and $50.01 / 5.00 ; 50.01 / 4.95$ have been assigned to coupling of methylene protons $\mathrm{Ha} / \mathrm{Ha}$ ' and $\mathrm{Hb} / \mathrm{Hb}$ ' with methylene carbon $\mathrm{C} 1 / \mathrm{Cl}^{\prime}$, respectively. The crosspeaks $5 ; 6$ and $7 ; 8$ at $\delta 50.48 / 5.93 ; 50.48 / 5.87$ and 50.48/4.79; 50.48/4.73 have been assigned to coupling of methylene protons $\mathrm{Ha}$ '/ $\mathrm{Ha}$ and $\mathrm{Hb}^{\prime} / \mathrm{Hb}$ with methylene carbon $\mathrm{C} 1^{\prime} / \mathrm{C} 1$, respectively.

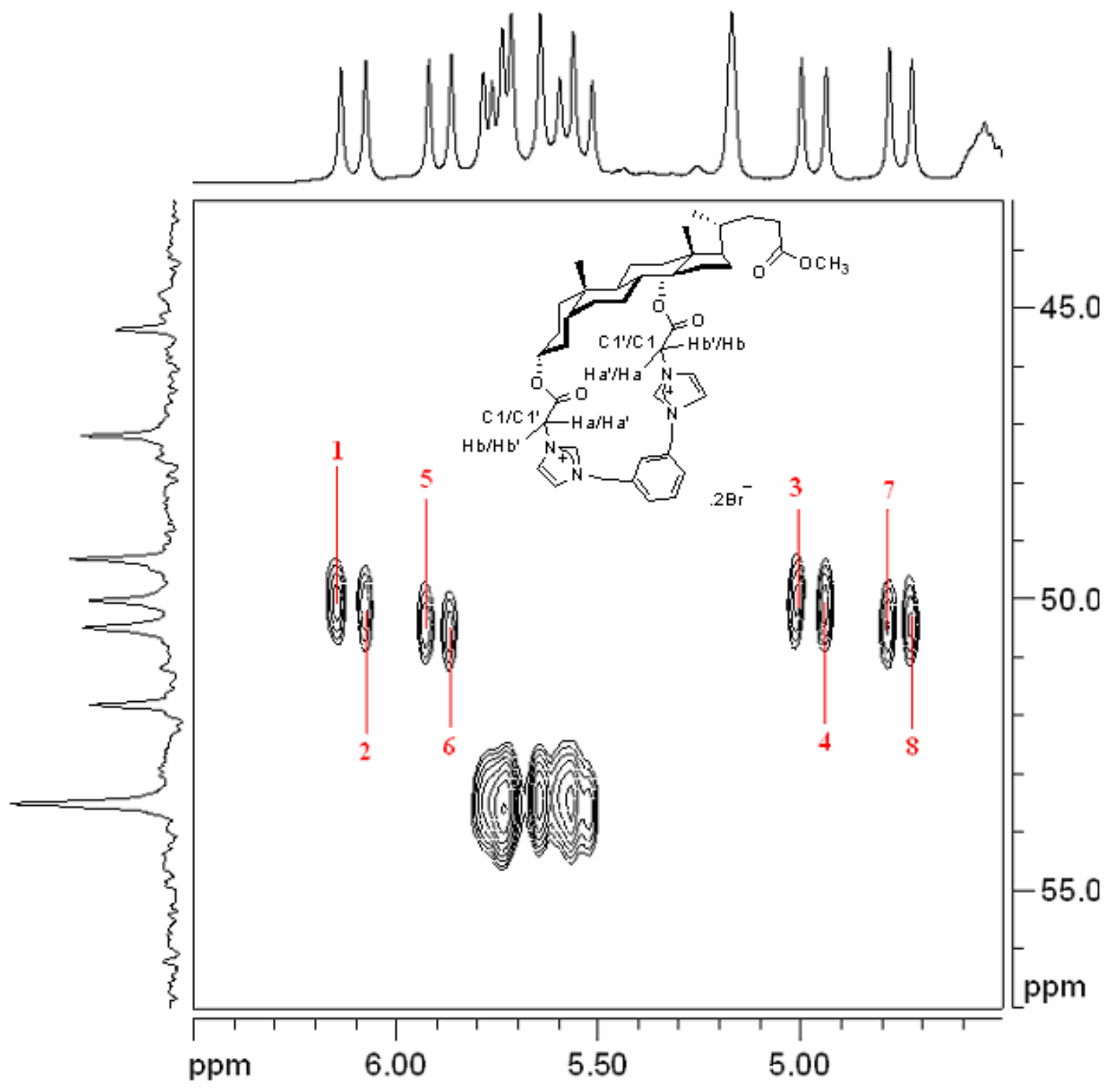

Figure S1. Expanded region of HSQC spectrum of 3-(Br $)_{2}$ 


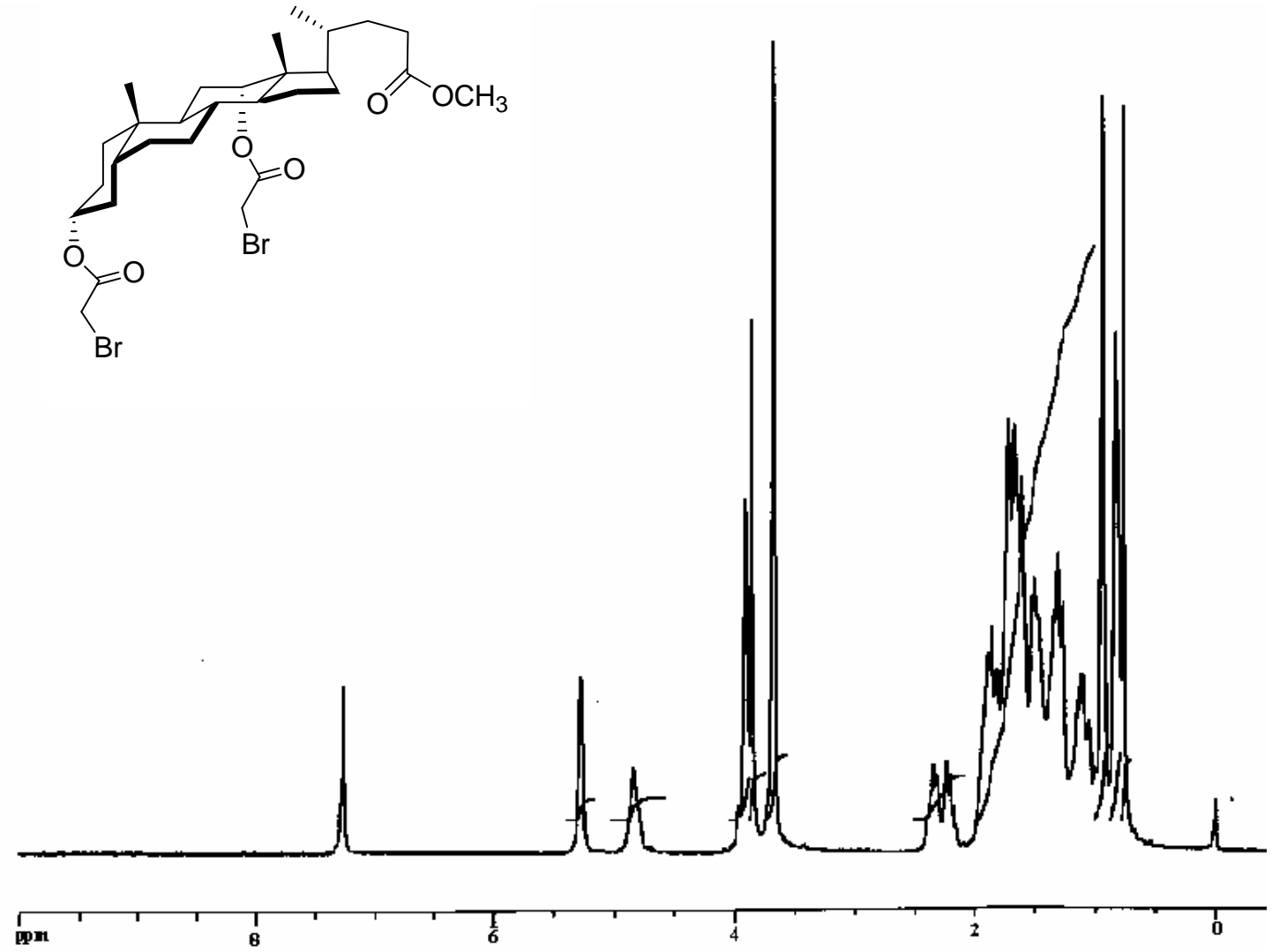

Figure S2. ${ }^{1} \mathrm{H}$ NMR spectrum of $3 \alpha, 12 \alpha$-bis-(bromoacetyl)deoxycholate 1a 


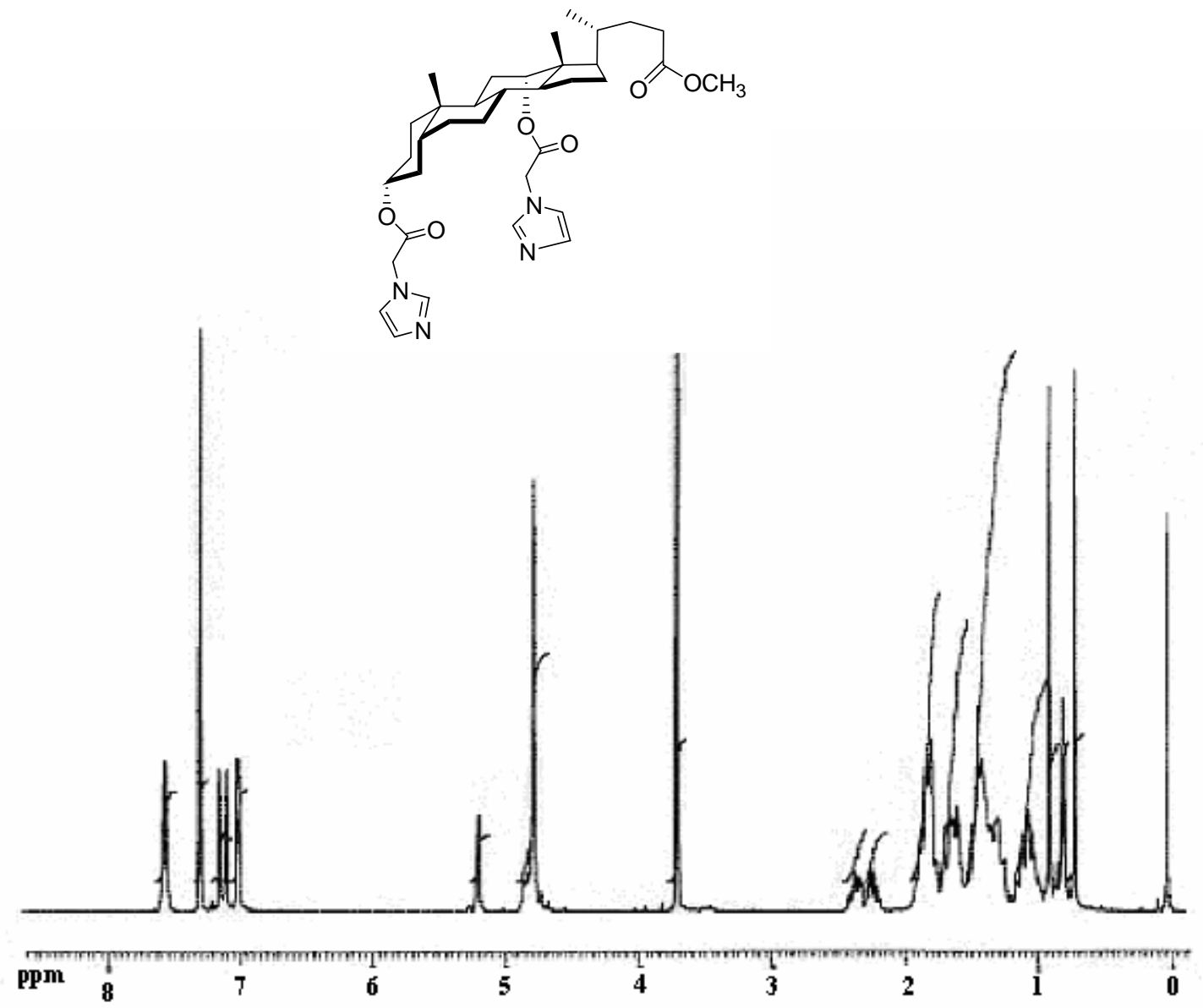

Figure S3. ${ }^{1} \mathrm{H}$ NMR spectrum of $3 \alpha, 12 \alpha$-bis- $\{\mathrm{O}-(\mathrm{N} 1$-imidazole) acetyl $\}$ deoxycholate 2 

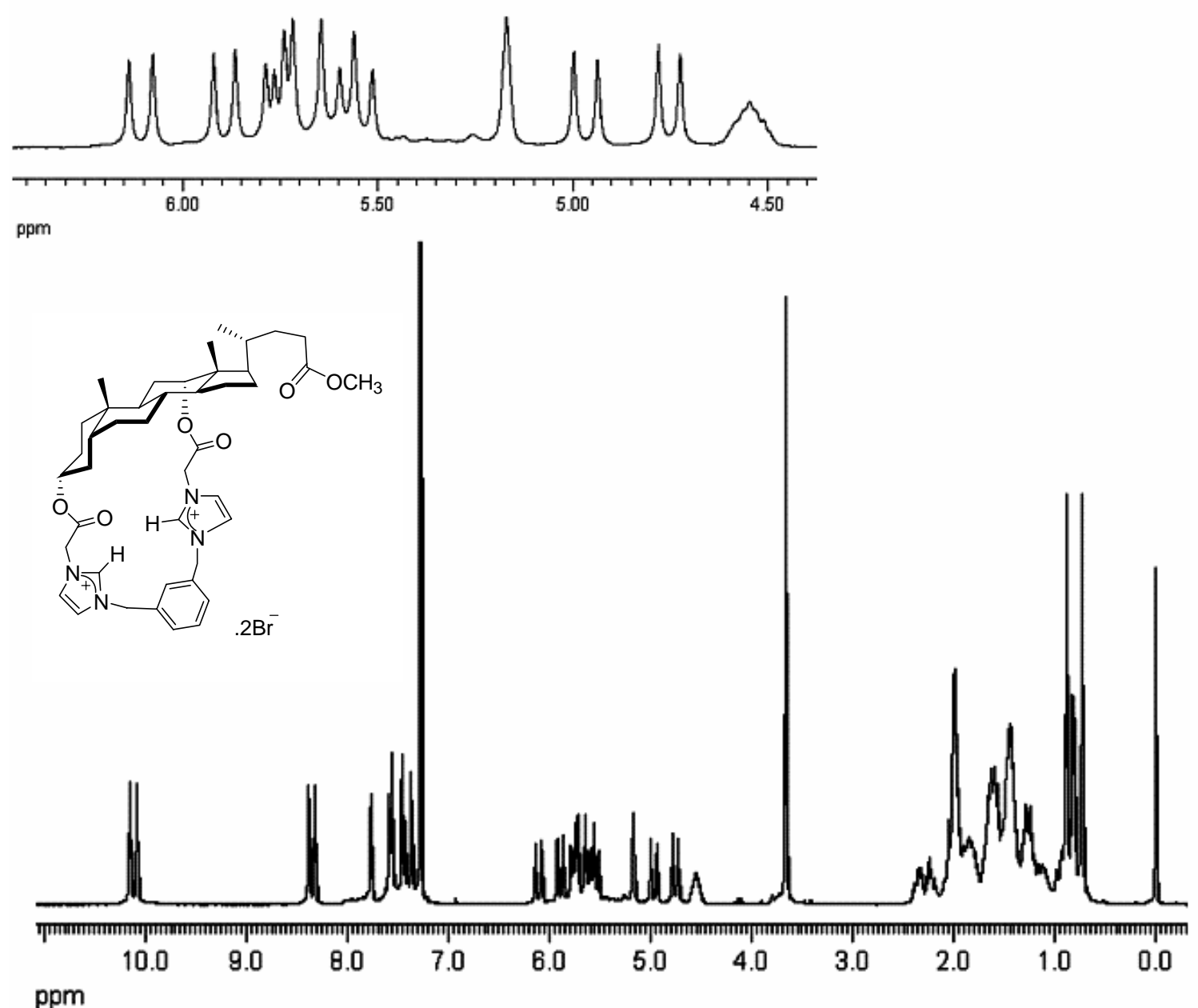

Figure S4. ${ }^{1} \mathrm{H}$ NMR spectrum of $3-(\mathrm{Br})_{2}$ 

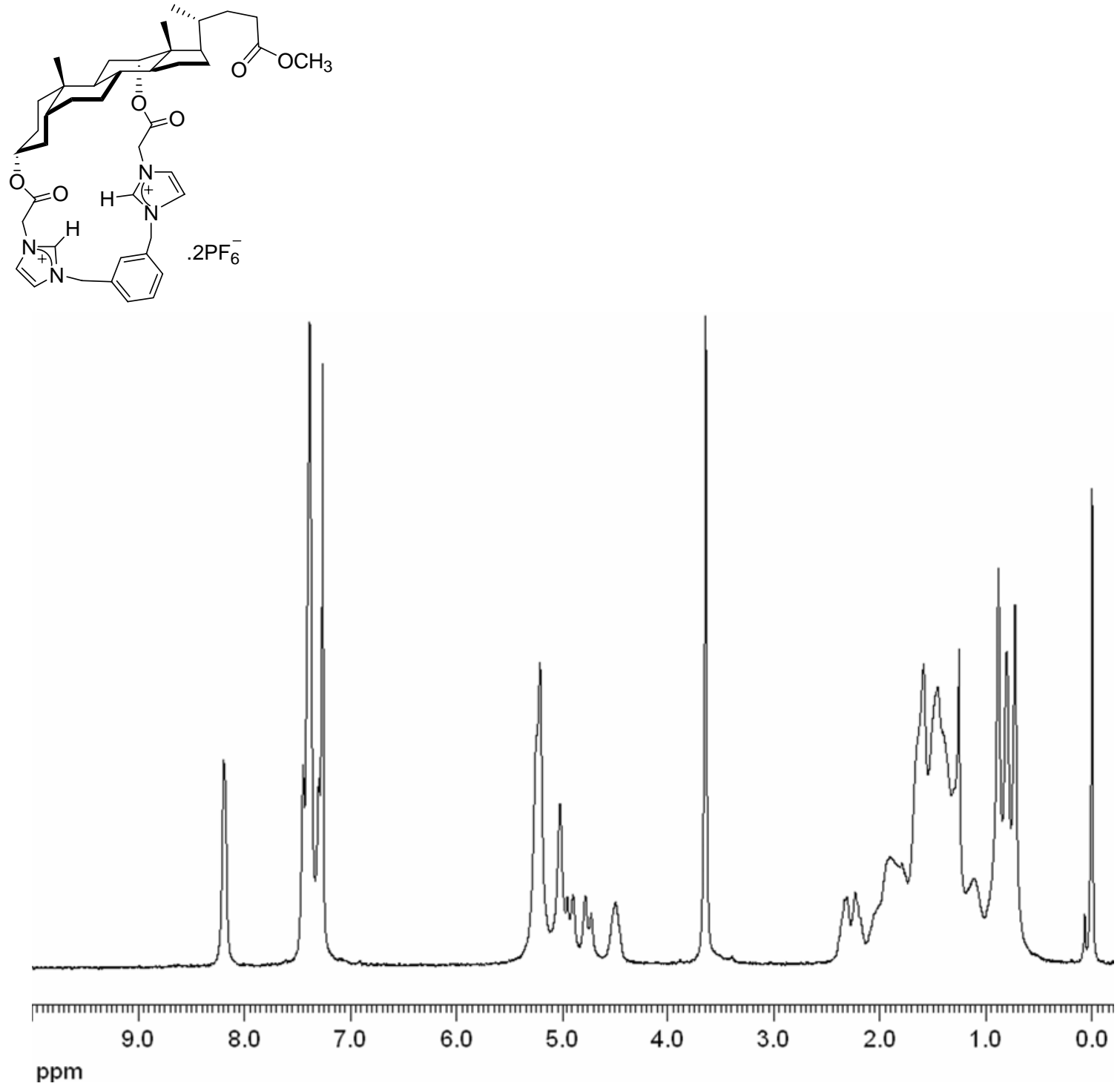

Figure S5. ${ }^{1} \mathrm{H}$ NMR spectrum of 3-( $\left(\mathrm{PF}_{6}\right)_{2}$ 

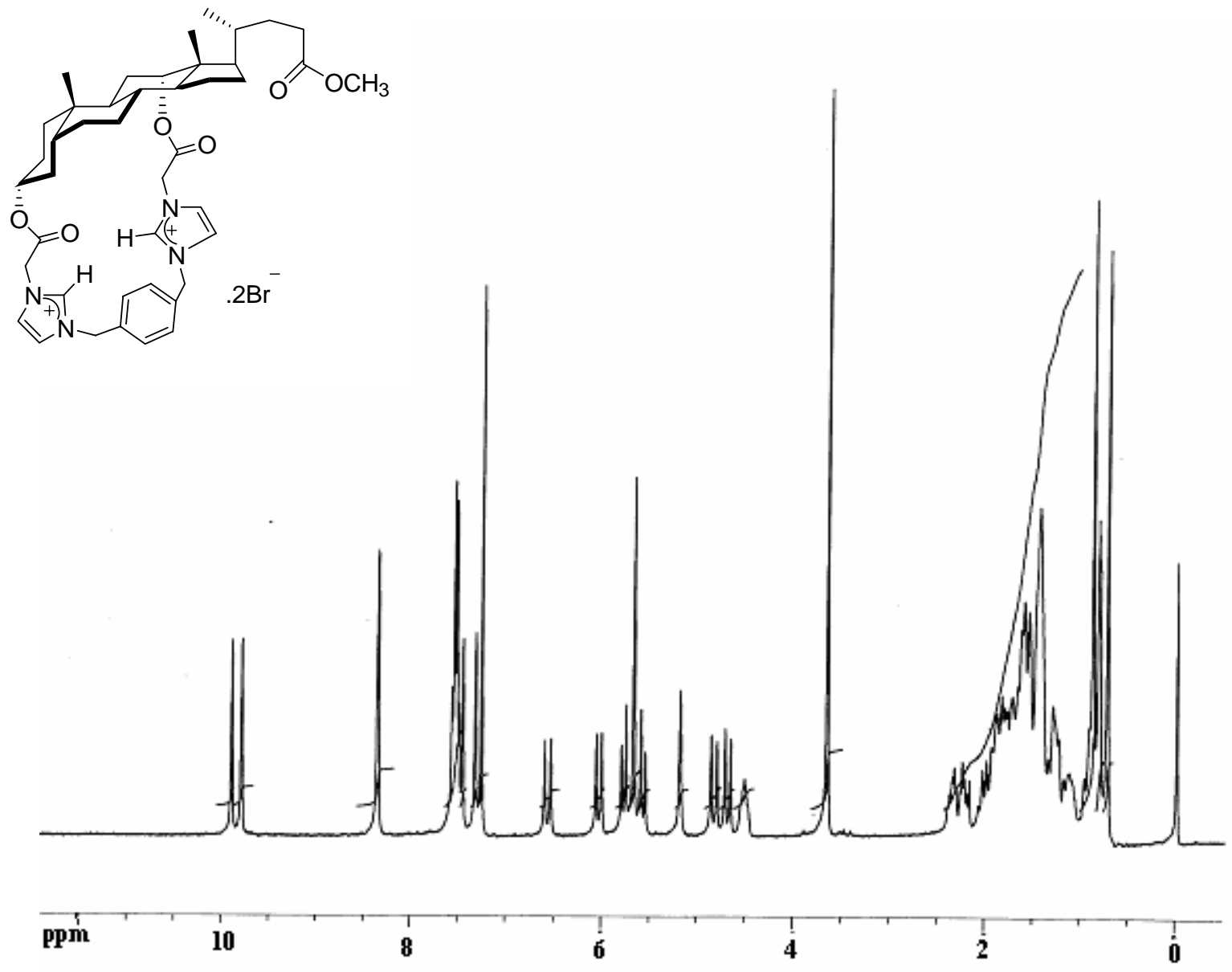

Figure S6. ${ }^{1} \mathrm{H}$ NMR spectrum of $4-(\mathrm{Br})_{2}$ 


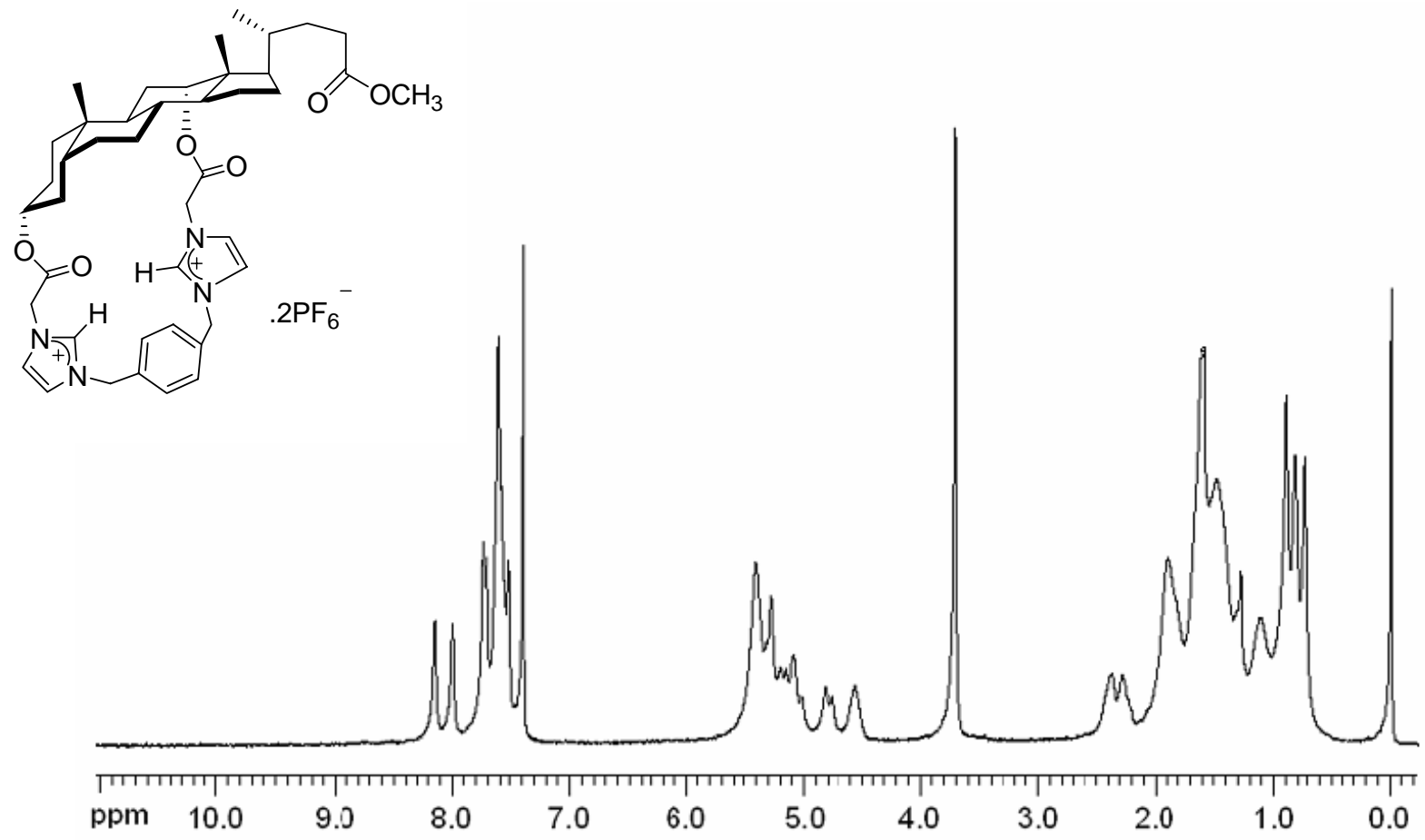

Figure S7. ${ }^{1} \mathrm{H}$ NMR spectrum of 4-( $\left(\mathrm{PF}_{6}\right)_{2}$ 

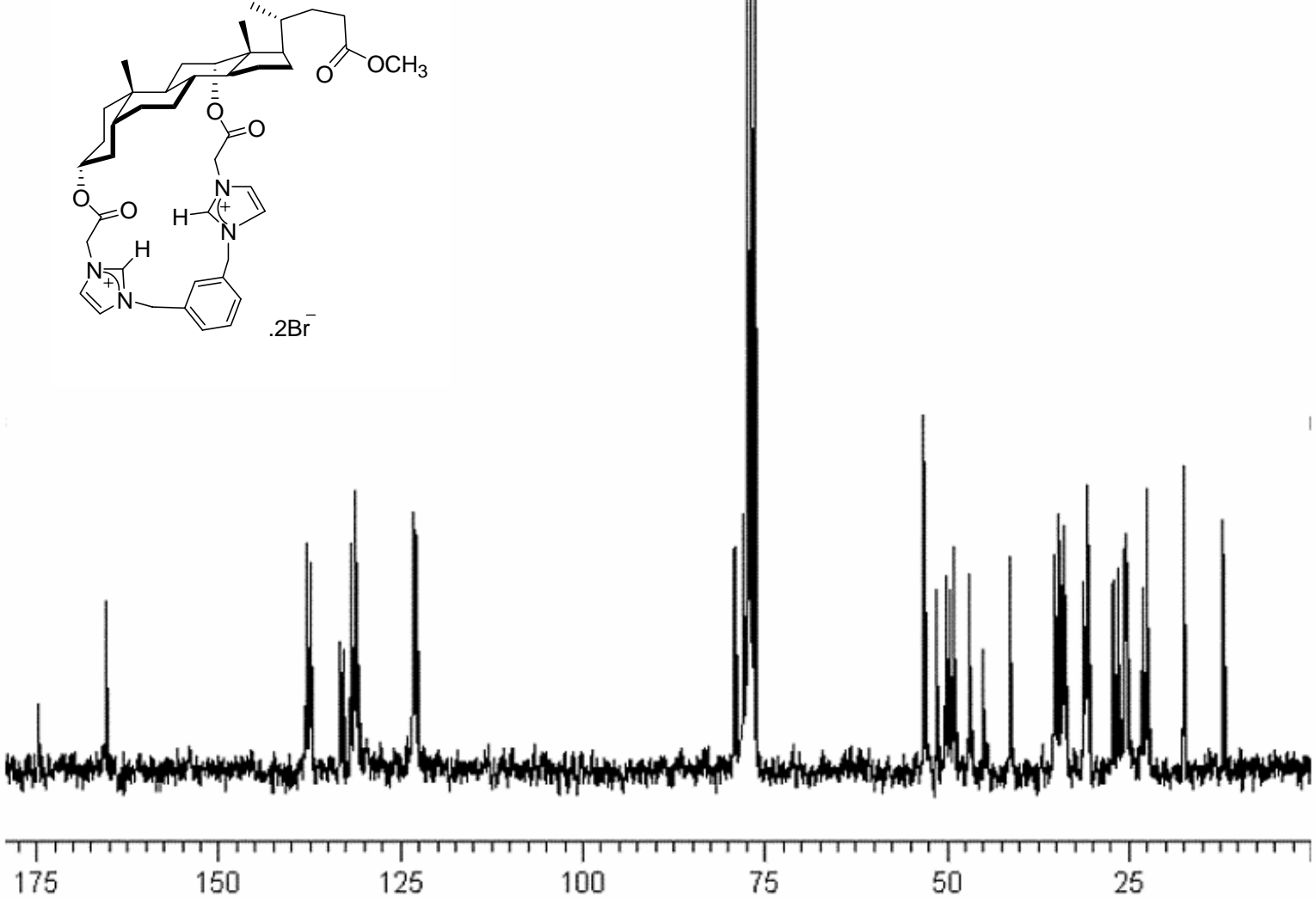

ppm

Figure S8. ${ }^{13} \mathrm{C}$ NMR spectrum of 3-(Br $)_{2}$ 

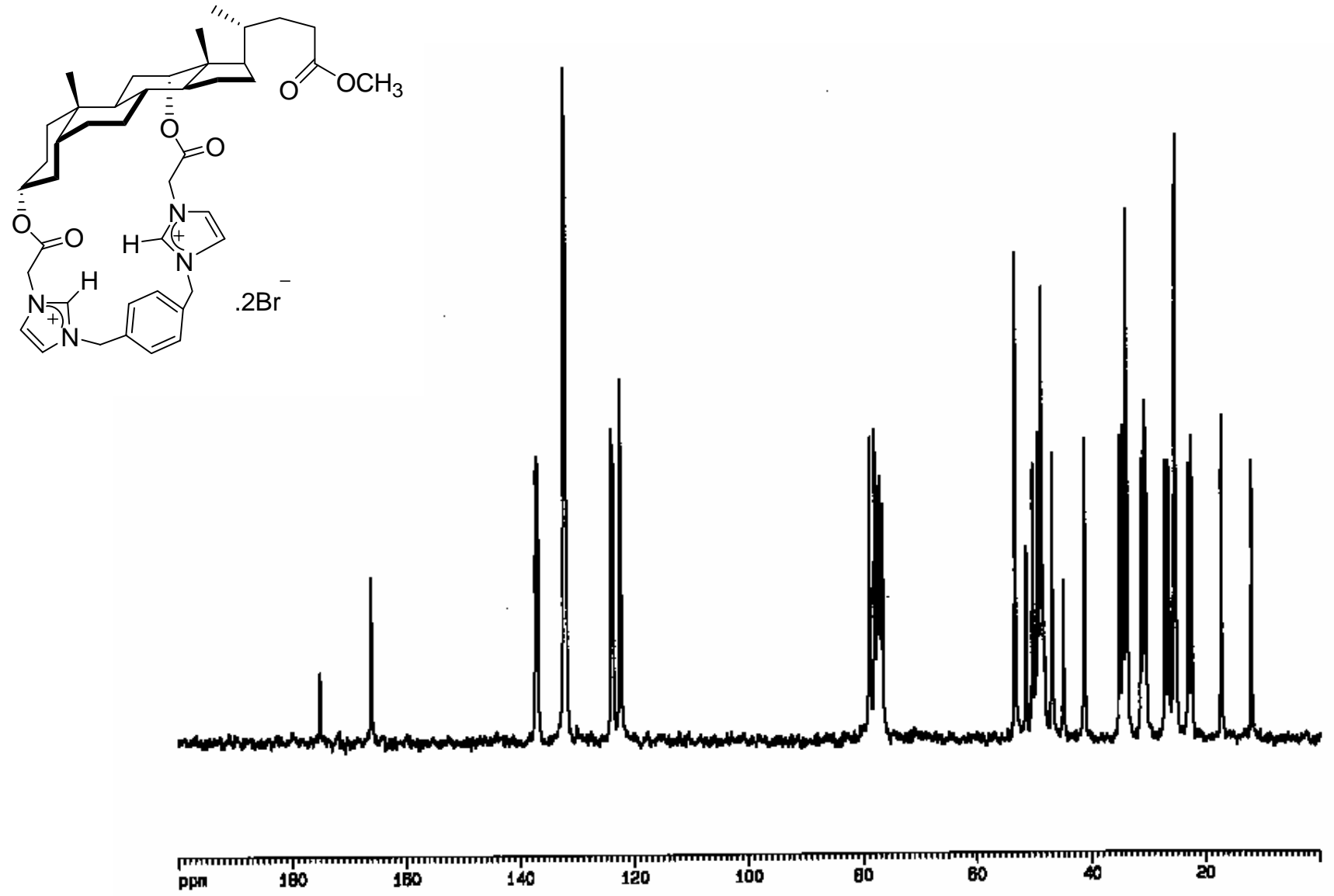

Figure S9. ${ }^{13} \mathrm{C}$ NMR spectrum of $4-(\mathrm{Br})_{2}$ 


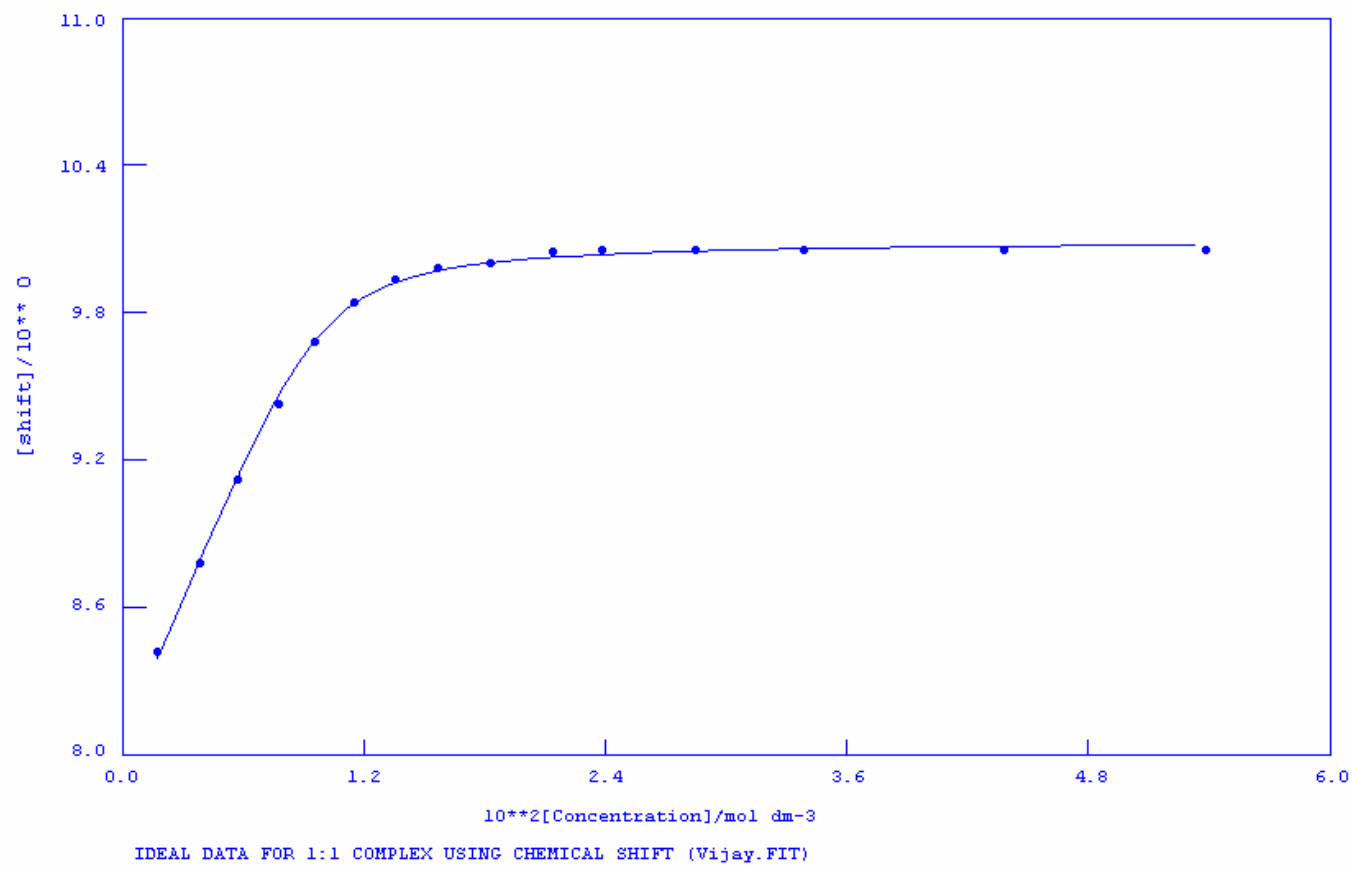

Figure S10. Binding isotherm for C(2) proton of imidazolium in receptor $\mathbf{3}$ with Tetrabutylammonium fluoride 


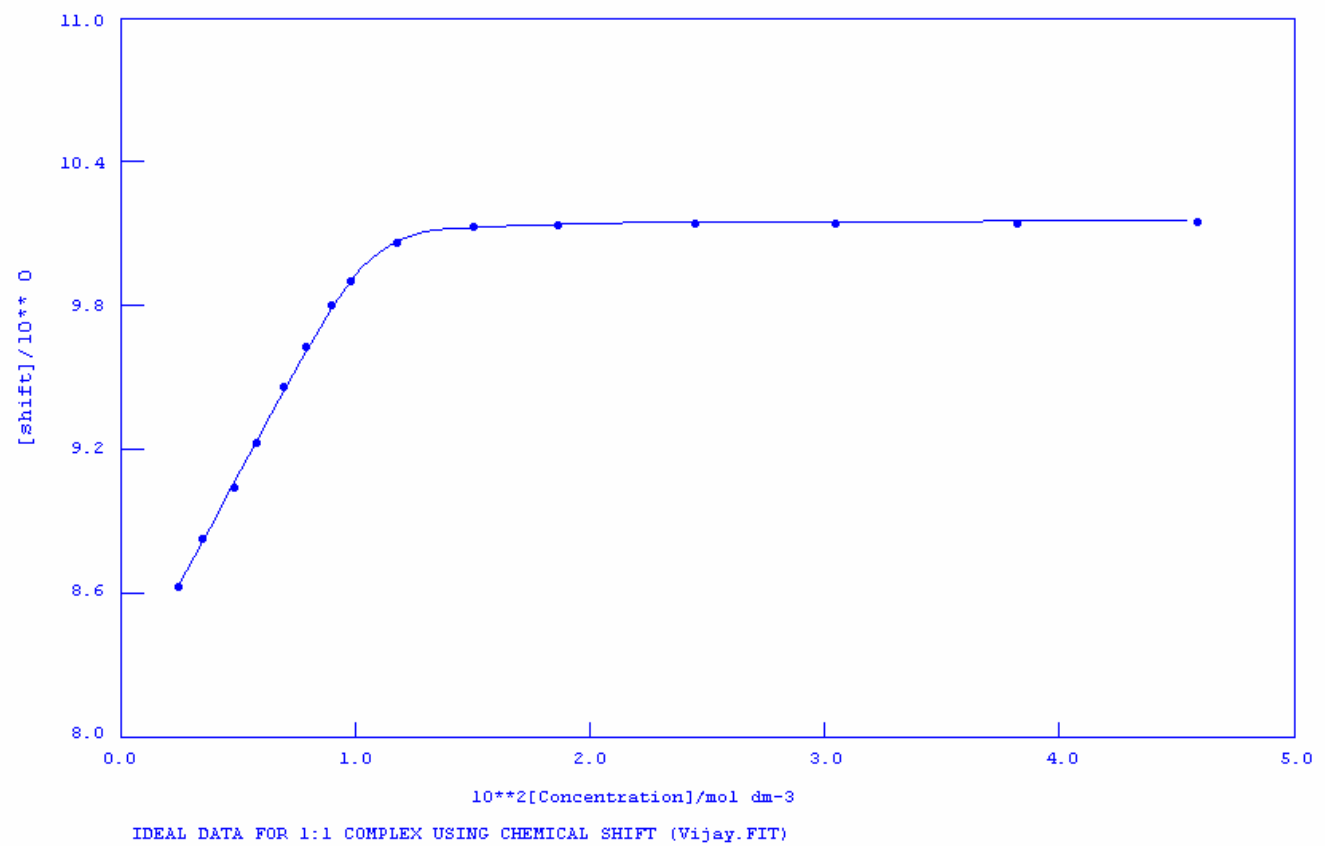

Figure S11. Binding isotherm for C(2) proton of imidazolium in receptor 4 with Tetrabutylammonium chloride 


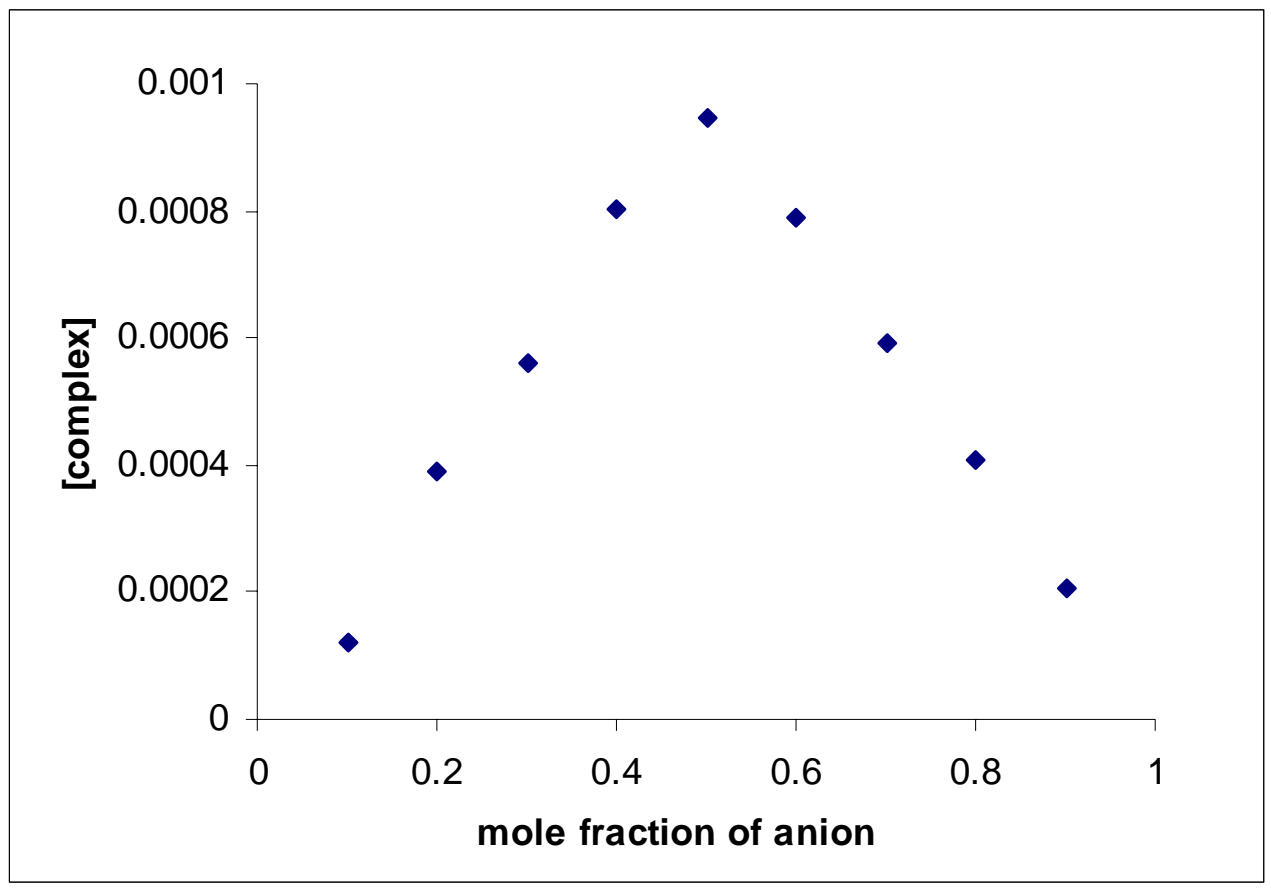

Figure S12. Job plot of receptor 3 with $\mathrm{TBABr}$

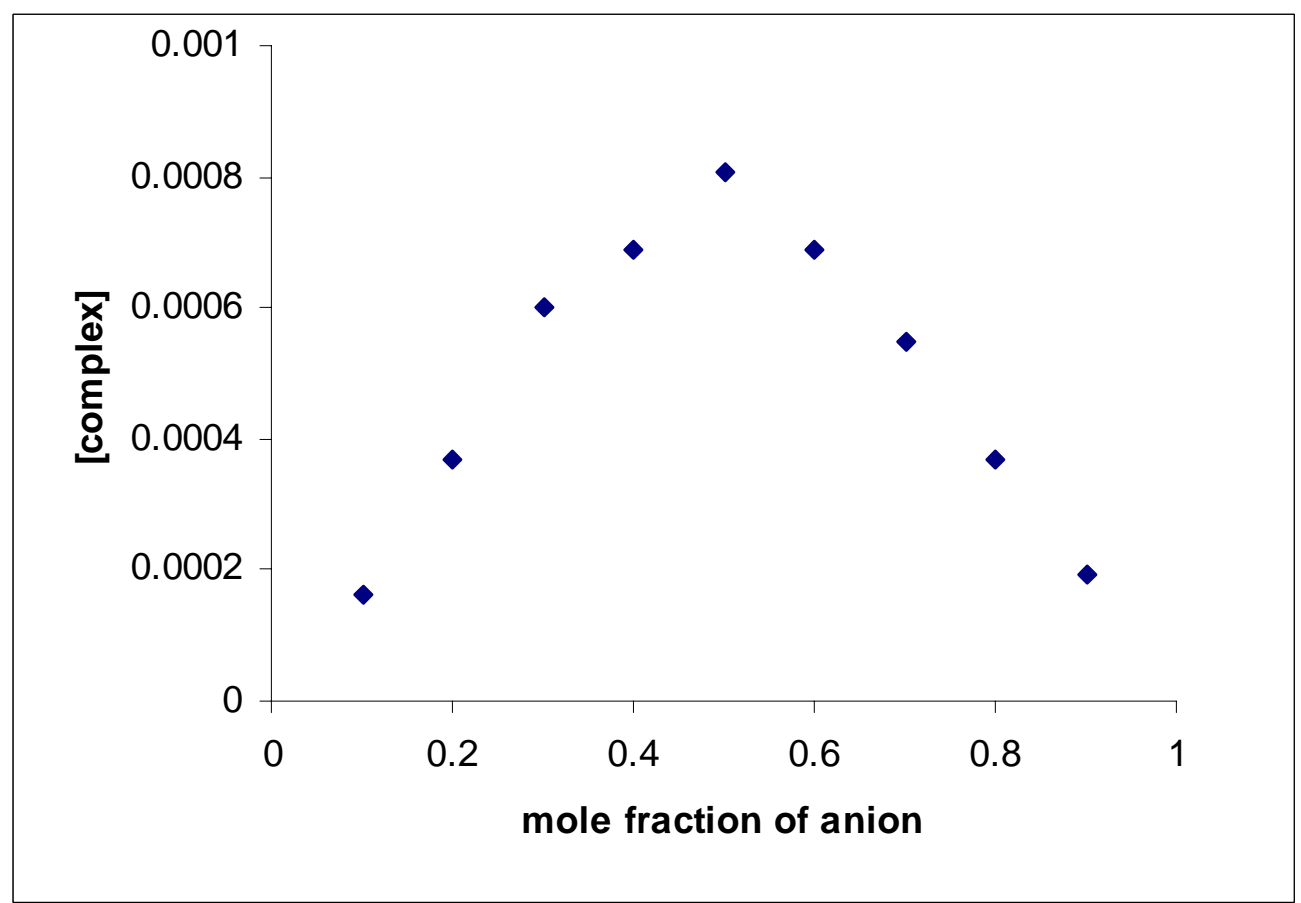

Figure S13. Job plot of receptor 4 with TBACl 